\title{
Upaya Peningkatan Kesadaran Masyarakat Dalam Konsumsi Susu Dan Olahannya Di Desa Cileles Kecamatan Jatinangor
}

\section{Community Awareness Efforts In Consumption Milk And Processing In Village Cileles District Jatinangor}

\author{
Hartati Chairunnisa ${ }^{1, a}$, Lilis Nurlina ${ }^{1}$, Hasni Arief $^{1}$, Eka Wulandari $^{1}$, Wendry S Putranto ${ }^{1}$, \\ Nanah $^{1}$ \\ ${ }^{1}$ Fakultas Peternakan Universitas Padjadjaran, Bandung \\ Jl. Raya Jatinangor Tlp. (022)7798241 Jatinangor-Majalengka 45363 \\ a email: hartati.chairunnisa@gmail.com
}

\begin{abstract}
Abstrak
Dalam upaya meningkatkan kesadaran masyarakat dalam mengkonsumsi susu dan produk olahannyadiperlukan kegiatan pelatihan dan penyuluhan berkaitan susu dan produk olahannya. Kegiatan pelatihan dan penyuluhan telah dilaksanakan kepada Ibu -Ibu PKK di Desa Cileles Kecamatan Jatinangor dan diharapkan melalui kegiatan tersebut dapat meningkat kesadaran untuk mengkonsumsi susu dan olahannya terutama bagi anak-anak dan balita. Kegiatan penyuluhan meliputi pre-test, penyuluhan tentang susu dan produk olahan (susu Pasteurisasi dan Susu Kental Manis), praktek pengolahn susu serta post-test. Kegiatan pelatihan menunjukan peningkatan pengetahuan yang signifikan dengan nilai rata-rata pada pre-test 49,40 persen, terjadi peningkatan penegetahuan pada saat post test mencapai nilai rata-rat 95,24 persen. Hal ini menunjukkan bahwa diperlukan upaya penyuluhan secara berkala dan rutin untuk lebih membudayakan untuk mengkonsumsi susu.
\end{abstract}

Kata kunci: olahan susu, susu, desa cileles

\begin{abstract}
In an effort to increase public awareness in consuming milk and processed products, training and counseling activities are needed regarding milk and processed products. Training and counseling activities have been carried out to the mothers of PKK in Cileles Village, Jatinangor Subdistrict and it is hoped that through this activity awareness can be increased to consume milk and its processed products, especially for children and toddlers. Extension activities included pre-tests, counseling on milk and processed products (Pasteurized milk and Sweetened condensed milk), milk processing practices and post-tests. Training activities showed a significant increase in knowledge with an average value in the pre-test 49.40 percent, there was an increase in knowledge when the post-test reached an average score of 95.24 percent. This shows that regular and routine counseling efforts are needed to be more civilized to consume milk.
\end{abstract}

Keywords : dairy products, milk, cileles village

\section{Pendahuluan}

Desa Cileles Kecamatan Jatinangor memiliki luas 320 ha dengan curah hujan sebesar $2000 \mathrm{~mm} / \mathrm{th}$, dengan jumlah bulah hujan sebanyak tujuh bulan. Suhu rata-rata harian sebesar Di desa Cileles terdapat perkebunan kelapa dengan luas 1 ha dan menghasilkan 2,5 ton/ha. Kemudian terdapat perkebunan tembakau dengan luas lahan sebesar 4 ha yang menghasilkan 1 ton/ha. Desa Cileles mememiliki lokasi berdekatan dengan kampus Universitas Padjadjaran di Jatinnagor.
Sebagai bagian dari kegiatan pemberdayaan masyarakat di sekitar kampus terutama untuk meningkatkan kesadaran gizi masyarakat maka diperlukan pembinaan secara berkala terutama berkaitan konsumsi sumber protein hewani.

Kesadaran masyarakat terutama Desa Cileles untuk mengkonsumsi susu segar masih rendah dan masih sedikit yang mengolah sendiri susu segar untuk konsumsi keluarga mereka. Sehingga melalui kegiatan ini diharapkan dapat memberikan pengetahuan, pemahaman serta keterampilan dalam mengolah susu menjadi produk susu 
Pasteurisasi dan Susu Kental Manis (SKM). Pendekatan melalui pelatihan dengan praktek langsung dalam pengolahan hasil ternak menunjukkan peserta pelatihan yang lebih antusias dalam mengikuti acara pelatihan (Sri Gustina dkk., 2016).

Susu segar didefinisikan sebagai cairan yang berasal dari ambing sapi yang sehat dan bersih yang diperoleh dengan cara pemerahan yang benar yang kandungan alaminya tidak dikurangi atau ditambah sesuatu serta belum mendapat perlakuan apapun (Winarno dan Fernandez,2007). Susu Pasteurisasi adalah susu segar yang telah mengalami proses pasteurisasi. Proses pasteurisasi termasuk proses pemanasan yang dapat didefenisikan sebagai berikut: pasteurisasi adalah proses pemanasan setiap komponen (partikel) dalam susu pada suhu $62^{\circ} \mathrm{C}$ selama 30 menit, atau pemanasan pada suhu $72^{\circ} \mathrm{C}$ selama 15 detik, yang segera diikuti dengan proses pendinginan (Badan Standarisasi Nasional Indonesia,1995). Susu kental manis merupakan produk susu berbentuk cairan kental yang diperoleh dengan menghilangkan sebagian air dari susu segar atau hasil rekonstitusi susu bubuk berlemak penuh, atau hasil rekombinasi susu bubuk tanpa lemak dengan lemak susu/lemak nabati, yang ditambahkan gula, dengan atau tanpa penambahan bahan makanan lain dan bahan tambahan makanan lain diizinkan (Badan Standarisasi Nasional Indonesia, 1998). Susu kental manis diperoleh dengan cara mengurangi (menguapkan) kandungan air susu sampai kandungan airnya tinggal sekitar $40 \%$. Dengan kadar air yang rendah ini susu dapat tahan disimpan lama dalam keadaan baik.

\section{Materi dan Metode Pelaksanaan}

Penyuluhan dan pelatihan dilaksanakan dengan sasaran Ibu-Ibu PKK dengan rangkaian kegiatan meliputi penjelasan teori tentang pengetahuan bahan pangan dalam hal ini susu serta produk olahannnya yaitu susu Pasteurisasi dan Susu Kental Manis (SKM), selanjutnya praktek pembuatan produk. Untuk megetahui tingkat pengetahuan dan pemahaman tentang susu Pasteurisasi dan SKM maka dilakukan pre-test dan selanjutnya setelah mendapatkan penjelasan serta praktek langsung maka dilakukan post-test. Dilakuan analisis terhadap presentase pemahaman dan penguasaan teknologi dari hasil pre-test dan post-test.

\section{Realisasi Pemecahan Masalah}

Penyampaian materi dan pelatihan pembuatan aneka olahan susu di Desa Cileles Kecamatan Jatinangor Kabupaten Sumedang dilaksanakan di Balai Desa Cileles pada tanggal 7 November 2018. Penyampaian teori dan penyuluhan dilaksanakan dengan metode diskusi tanya jawab, kemudian dilanjutkan dengan praktik pembuatan susu Pasteurisasi dan Susu Kental Manis (SKM).

\section{Praktek Pembuatan Susu Pasteurisasi dan SKM}

Pembuatan Susu Pasteurisasi :

1. Susu segar dimasukkan dalam panci stainless steel.

2. Selanjutnya panaskan pada $72^{\circ} \mathrm{C}$ selama 15 detik/ (atau sampai mendidih).

3. Segera dinginkan $4^{0} \mathrm{C}$ dengan air atau udara dingin dan tambahkan flavor sesuai dengan selera.

Pembuatan SKM :

1. Susu segar sebanyak 1 liter dan ditambahkan 200 gram gula pasir.

2. Selanjutnya dipanaskan hingga suhu $60-65^{\circ} \mathrm{C}$ (tidak mendidih) sambil dilakukan pengadukan, sesudah mencapai suhu yang diinginkan, suhu tetap dipertahankan selama penguapan.

3. Pengadukan terus dilakukan untuk mencegah susu berubah warnanya sampai volume tinggal $1 / 3$.

4. Setelah didapatkan perbandingan yang tepat, masukkan susu ke dalam botol steril dan secepatnya lakukan pendinginan hingga mencapai suhu $15-18^{\circ} \mathrm{C}$

\section{Hasil dan Pembahasan}

Program pengabdian kepada masyarakat yang dilaksanakan pada bulan Oktober dan November 2018 diikuti oleh Ibu-Ibu PKK Desa Cileles Kecamatan Jatinnagor Kabupaten Sumedang. Dalam program pelatihan yang dilaksanakan diikuti secara antusias oleh peserta penyuluhan. Jumlah peserta pelatihan dan penyuluhan adalah 30 orang. Pelaksanaan pelatihan pada 17 November 2018, pukul 13.00 - 15.30 WIB di Ruang Pertemuan Balai Desa Cileles Kecamatan Jatinangor Kabupaten Sumedang. 
Indikator keberhasilan kegiatan pengabdian kepada masyarakat berdasarkan pengamatan langsung selama kegiatan berlangsun dan pengisian lembar kuisioner (Tabel.1. ) yang dilanjutkan dengan analsisis.

Berdasarkan pada hasil analisis pada Tabel.1. menunjukkan terjadi peningkatan dan pengetahuan Ibu-Ibu PKK Desa Cileles berkaitan dengan pengolahan susu segar menjadi produk susu Pasteurisasi dan Susu Kental Manis. Pada saat pre test mencapai 49,40 persen menjadi 95,24 persen pada post test. Pengetahuan meliputi karakteristik mutu produk susu Pasteurisasi, proses pembuatan susu Pasteurisasi, Variasi tahapan pembuatan susu Pasteurisasi, cara penyimpanan produk susu Pasteurisasi, karakteristik produk Susu Kental Manis (SKM), serta bahan baku pembuatan SKM. Sebagian besar peserta belum pernah membuat sendiri baik susu Pasteurisasi maupun SKM, dan lebih menyukai selama ini membeli langsung produk tersebut dipasaran. Melalui kegiatan praktek langsung diharapkan dapat meningkatkan pengalaman bagi peserta. Pengalaman memudahkan minat timbul bila terjadi perubahan mentalitas, pengetahuan, kecakapan, dan keterampilan (Wiriaatmadja, 1982).

Dalam penyuluhan dan pelatihan disamping penjelasan teori pembuatan produk juga langsung melakukan praktek pengolahan dengan dibagi menjadi 4 (empat) kelompok dan produk yang telah jadi dipresentasikan serta dilakukan pengujian dengan dikonsumsi bersama. Praktek secara langsung dapat meningkatkan keterampilan dalam pengolahan susu menjadi produk olahan (Sahadi, dkk., 2018).

Tabel.1. Hasil Analsis Kuesioner Pre-Test dan Post-Test

\begin{tabular}{|c|c|c|c|c|c|}
\hline \multirow{2}{*}{ No } & \multirow{2}{*}{ Pengetahuan } & \multicolumn{2}{|c|}{$\begin{array}{l}\text { Sebelum Pelatihan } \\
\text { (\% jawaban) }\end{array}$} & \multicolumn{2}{|c|}{$\begin{array}{l}\text { Setelah Pelatihan } \\
\text { (\% jawaban) }\end{array}$} \\
\hline & & Benar & Salah & Benar & Salah \\
\hline 1 & $\begin{array}{l}\text { Karakteristik mutu produk susu } \\
\text { Pasteurisasi }\end{array}$ & 38,10 & 61,90 & 85,71 & 14,29 \\
\hline 2 & Proses pembuatan susu Pasteurisasi & 47,62 & 52,38 & 95,24 & 4,76 \\
\hline 3 & $\begin{array}{l}\text { Variasi tahapan pembuatan susu } \\
\text { Pasteurisasi }\end{array}$ & 47,62 & 52,38 & 100,00 & 0,00 \\
\hline 4 & $\begin{array}{l}\text { Cara penyimpanan produk susu } \\
\text { Pasteurisasi }\end{array}$ & 57,14 & 42,86 & 90,48 & 9,52 \\
\hline 5 & $\begin{array}{l}\text { Karakteristik produk Susu Kental } \\
\text { Manis (SKM) }\end{array}$ & 71,43 & 28,57 & 95,24 & 4,76 \\
\hline 6 & Bahan baku pembuatan SKM & 61,90 & 38,10 & 100,00 & 0,00 \\
\hline 7 & Tahapan pembuatan SKM & 38,10 & 61,90 & 100,00 & 0,00 \\
\hline \multirow[t]{2}{*}{8} & Cara penyimpanan produk SKM & 33,33 & 66,67 & 95,24 & 4,76 \\
\hline & Rataan Total & 49,40 & 50,60 & 95,24 & 4,76 \\
\hline
\end{tabular}



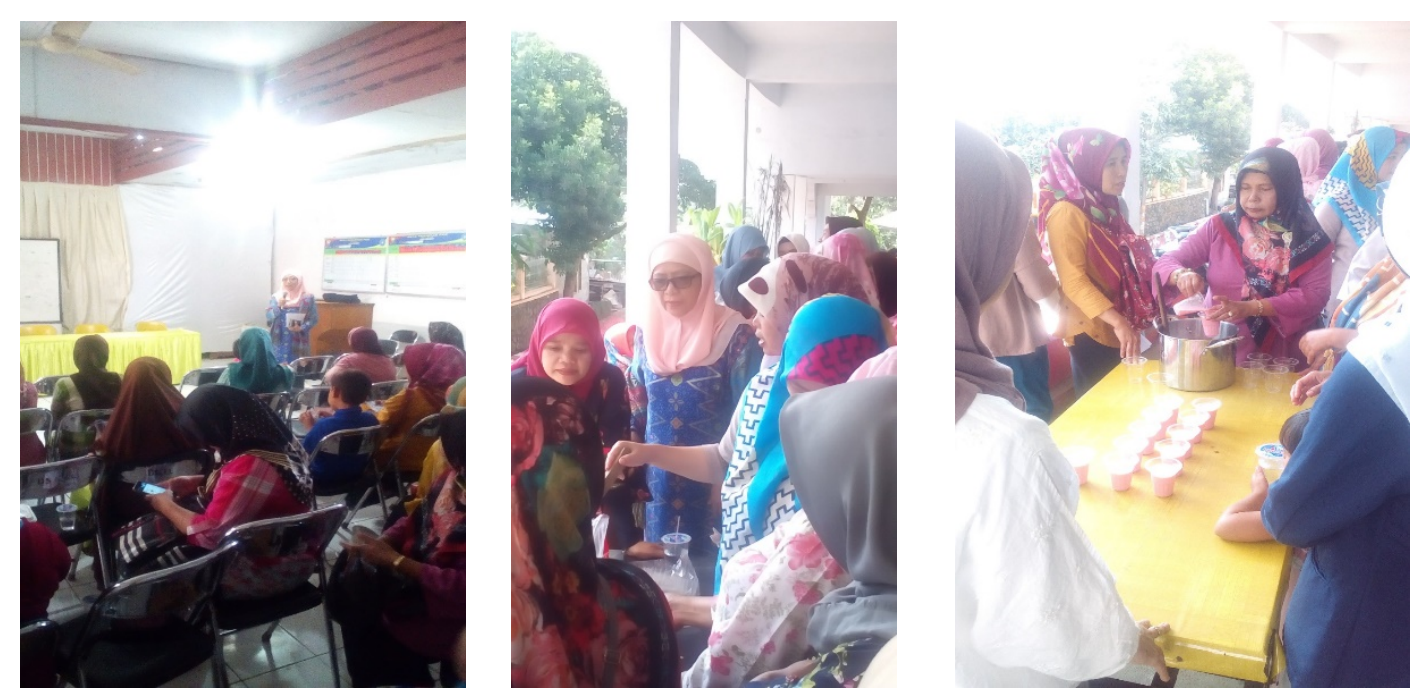

Ilustrasi.1. Foto dokumentasi kegiatan pelatihan dan penyuluhan.

Melalui metode ini diharapkan penyuluhan dan pelatihan akan berjalan menyenangkan dan diharapkan dapat meningkatkan kesadaran masyarakat Desa Cileles untuk mengkonsumsi susu dengan cara mengolah sendiri. Diharapkan pula dengan pelatihan ini dapat memotivasi Ibu-Ibu PKK untuk merintis home industry dan dapat membantu meningkatkan pendapatan dan kesejahteraan keluarga. Kegiatan program pengabdian kepada masyarakat dapat mendorong dan mendukung mitra untuk menciptakan dampak yang positif bagi kemandirian dan produktivitas masyarakat (Waluyo, dkk., 2018). Disamping itu upaya pendampingan diharapkan menumbuhkan jiwa kewirausahaan dalam pengolahan susu (Franciscus, dkk., 2018). Hal ini juga terjadi dalam pelatihan Ibu-Ibu PKK di Kelurahan Cepoko Gunungpati Semarang dalam mengolah susu menjadi stik susu mengharapakan pendampingan lebih lanjut dalam pengembangan usahanya (Ari, dkk., 2017). Kegiatan pelatihan yang dilakukan di Kecamatan Mulyorejo Surabaya juga mampu meningkatkan kesadaran dan keterampilan masyarakat dalam mengolah susu menjadi produk dengan nilai ekonomi lebih tinggi (Dandy, dkk., 2018).

\section{Kesimpulan}

Kegiatan pelatihan dan penyuluhan yang telah dilaksanakan pada Ibu-Ibu PKK Desa Cileles Kecamatan Jatinnagor dapat meningkatkan pengetahuan dan keterampilannya dalam mengolah susu segar menjadi produk olahan yaitu susu Pasteurisasi dan Susu Kental Manis (SKM). Kegiatan penyuluhan dan pelatihan dengan jenis produk pangan olahan hasil ternak yang lain sangat diperlukan masyarakat untuk menambah pengetahuan dan keterampilan dalam upaya pemberdayaan masyarakat serta menumbuhkan wirausaha baru.

\section{Ucapan Terimakasih}

Program Pengabdian Kepada Masyarakat ini merupakan bagian dari kegiatan Hibah Riset ALG Tahun 2018. Ucapan terimakasih kepada Rektor Universitas Padjadjaran atas pendanaan Hibah Academic Leardership Grant (ALG) Tahun 2018.

\section{Daftar Pustaka}

Ari Y, Ning S, Susanti R.2017.Pengembangan Olahan Hasil Ternak Melalui Diversifikasi Produk Berbahan Dasar Susu di Kelurahan Cepoko Gunungpati Semarang. Rekayasa. Vol.15. No.1. Hal : 11-16.

\begin{tabular}{|c|c|c|}
\hline Badan & \begin{tabular}{l}
\multicolumn{1}{c}{ Standarisasi } \\
Indonesia.1995.Susu \\
Pasteurisasi.SNI.01-39
\end{tabular} & $51-1995$. \\
\hline Badan & \begin{tabular}{l}
\multicolumn{1}{c}{ Standarisasi } \\
Indonesia.1998.Susu \\
Manis.SNI.01-2971-19
\end{tabular} & $\begin{array}{r}\text { Nasional } \\
\text { Kental }\end{array}$ \\
\hline Shandy & $\begin{array}{c}\text { KW, } \quad \text { Soetji } \\
\text { HE.2017.Pengabdian }\end{array}$ & P, $\begin{array}{r}\text { Mustofa } \\
\text { Masyaraka }\end{array}$ \\
\hline & $\begin{array}{l}\text { Pelatihan pembuatan } \\
\text { Masyarakat Peternak S }\end{array}$ & i Perah di \\
\hline
\end{tabular}


Kecamatan Mulyorejo Surabaya. Agroveteriner.Vol.5.Hal:158-162.

Fransiscus ASJS, Rubiyanto, Yohanes D.2018.IbM Peternak Sapi Perah dan Pengolahan Susu di Pakem Sleman.Jurnal Pengabdian Kepada Masyarakat.Vol.1.Hal.1-7.

Sahadi DI, Hasbullah, Anwar K, Fauzan A, Kesuma S, Rini, Novizar, Neswati, Tuty A, Netty SI.2018.Pelatihan Penanganan dan Pengolahan Susu Kambing di Nagari Bukit Batabuh Kabupaten

Agam.Logista.Vol.2.No.2.Hal: 32-39.

Sri Gustina, Sulmiyati, Magfirah, Marsudi.2016.Upaya Pembinaan Masyarakat Dalam Rangka Pengembangan Susu Kambing Pasteurisasi (Suke) pada Kelompok Tani di Desa Lambanan, Kecamatan Balanipan, Kabupaten Polewali Mandar, Sulawesi Barat. Indonesia Journal of Community Engagement.Vol.02. Hal : 101-110.

Waluyo ES, Enike DK, Aju TNK, Henny L, Dimas PPH, Tri IWK, Syam R.2018.Pelatihan dan Pendampingan Pengolahan Susu Afkir di Desa Kemantren Kecamatan Jabung.Conference on Inovation of Science Technology (CIASTECH). ISSN on line : 2622-1284.Universitas Widyagama Malang.

Winarno FG dan Fernandez IE.2007.Susu dan Produk Fermentasinya.Cetakan 1.Brio Press.Bogor.

Wiriaatmadja. 1982. Pokok-pokok Sosiologi Pedesaan. Cetakan kedelapan. Cv Yasaguna. Jakarta. Hal. 7-8. 